\title{
Syncretic Heritage of Bawakng Tradition for Salako Dayak (Bawakng as a Supreme Shrine)
}

\author{
By: Albertus \\ NARMAC (Natural Resource Management Collaboration) Institute \\ Jalan Purnama, Gang Purnama 4 No. 22B Pontianak. HP: 081351214702, \\ Email address: albertn89k@gmail.com
}

\begin{abstract}
Salako is the ethnonym denominating the ethnic group which straddles the border of two nation-states, Sarawak, Malaysia and West Kalimantan, Indonesia. The belief system of this community including to Bawakng traditions have been syncretized through inter-mingling with Hindu's beliefs during the Indianization of Southeast Asia. Bawakng is a mountain which is mythologized as the homeland of supreme dieties of Dayak Salako. Meanwhile, in Hindu's belief, Himalaya is a mountain as a supreme shrine. Both of these belief systems highly considered the big highest mountains as the homeland of supreme dieties. This syncretism can be seen in Salako religious beliefs, livelihood, customs and traditions. Local community believes that Bawakng Mountain is the shrine of the supreme deities. It also represents how Salakos construe themselves based on their Bawakng cosmogony. Salako and Hinduism have a belief in multiple deities, which are assembled into a pantheon, Bawakng for Salako and Himalaya for Hindu.
\end{abstract}

Key Word: Syncretism, Supreme Shrine, Deity, Seeking Identity

\section{INTRODUCTION}

There is a quotation in the entrance of Apollo Shrine at the Delphoi, a sacred place for pilgrims to Greece, "Gnoti Sauton" or "know yourself and don't be excessive'. The quotation itself can be translated into several different meanings. In this paper, it can be interpreted to mean that ethnic groups in their social life and interaction need to have an identity in the hope that they can declare who they are to other ethnic groups or outsiders. At a certain level, identity is needed by individuals or groups to proclaim themselves as those who affiliate with a certain entity. Smith (in Oomen 2009:54-55) formulated six characteristics of ethnicity, such as a collective name, an ancestor myth, collective history, unique collective culture, a strong link to certain territories, and a sentiment of solidarity. Dayak is the collective name applied to various sub-ethnic groups in Borneo. Salako (also spelled Selako) is one Dayak sub-ethnic group. Salako Dayaks evolved their mythology in the form of oral traditions inherited from their ancestors. This group of Dayaks developed a collective history and culture which can be traced through oral traditions. They also settled in and around Bawakng Mountain, considered a sacred mountain by several Dayak ethnic groups located in Bengkayang and Landak districts. Due to similarity in history, fate as suppresed people, and marginalization process, Salako Dayaks developed a solidarity sentiment or 'us feeling' amongst themselves.

But, who are the Salako Dayak people? What information do we use to identify them? And how did their territories form their identity as Salako Dayaks? These three questions will be attempted to be answered by proposing the hypothesis that Bawakng Mountain is the homeland of Salako Dayaks which indicated their existence and identity in oral tradition and local wisdom based on the syncretic phenomena. Syncretism is the combining of different beliefs. "Syncretism involves the merger and analogizing of several originally discrete traditions, especially in the theology and mythology of religion, thus asserting an underlying unity and allowing for an inclusive approach to other faiths. Syncretism also occurs commonly in expressions of arts and culture, (known as eclecticism) as well as politics (syncretic politics)."

(Source:

https://en.wikipedia.org/wiki/Syncretism.)

Jubata is the supreme Dayak Salako's diety. The method to experience the present of Jubata is by 'bapamang/ babamang / nyangahatn (the way to pray to Jubata). When Dayaks are praying 'bapamang/ nyangahatn', they always mention Jubata Bawakng (see also M.C. Shadee in 1903) translated by P. Yeri OFMCap, (2016:14). Regarding theogony or 'birth of the gods', M.C. Shadee (1903:39) wrote that jubata (deity) and good spirits are spread in natural elements such as small or big rivers, in the forests, in every mountain, with each mountain having its own 
deities (jubata). Ape' Mantuhari is considered the king of Bawakng Mountain.

In a Salako Dayak, healing ceremony named baliatn and the one who conduct baliatn called pamaliatn, the Dayak doctor who conducts baliatn, has to carry out a journey to the world of deities and human spirits in Bawakng Mountain to take back the spirit of sick or suffered person. Half of the journey must be carried out by a boat made of wood, while the rest must be done on foot. In the journey, the pamaliatn has to pass through some obstacles to chase the spirits of the sick, obstacles such as titi bajowa, meaning a bridge which split one another, titi bagintur meaning a shakeable bridge, titi bagora meaning a bridge which is cycling, titi sawa meaning a bridge which is full of sawa snakes, and titi mangunang meaning a bridge which is always swinging. In order to successfully pass the obstacles, the pamaliatn has to ask for help from deities and baras kuning/ baras banyu or yellow rice to expedite his task in the process of baliatn.

The next journey to the land of spirits is very difficult, but by having beras kuning or beras banyu all the obstacles can be overcome. After passing through titi bangunang, the pamaliatn will come to the next obstacle named tanah bagabut (the shakeable land), and then tanah balida or a booby trap full of thorns. After that, pamaliatn arrives at the saka baribu area which means thousand intersections. After passing through it, the pamaliatn comes to batu barapi (fiery stone), and finally he arrives at the land of spirits and deities. The land of spirits consists of many villages; to find the spirit of the sick person, the pamaliatn has to inquire of the spirits in each village to locate the sick person's spirit.

The third journey has Bawakng Mountain as its destination, the homeland of the deities. To go to Bawakng Mountain, the journey will again be conducted by boat and on foot. Yet, the journey to Bawakng also full of dangerous obstacles. With the help of Panyampakng (the one who helps the pamaliatn to stay standing and conscious) and baras kuning, the pamaliatn is able to arrive at the city of deities at the top of the Bawakng Mountain. In that city, he will meet the King of the city named Ape Mantuhari. Ape' Mantuhari will be ready to help Pamaliatn to cure the sick person. Ape' Mantuhari has subordinates such as Patih in Pakana area located at the Mampawah river basin, Jaya in Bauju area, Indar in Sampodo area and Lopo Panungkat Bawakng (title given to Nek Salopo as a reward to holdout Bawakng mountain in order not to fall down), (see Schadee 2016:129).

Dunselman (2016:69) in a footnote explained that the world of the dead or the land of spirits from dead people is called subayatn. Regarding the tradition of baras kuning or baras banyu, it is mythologized that Dayakng Langa Urakng Panariuatn who stays in Panariu Mountain (one of the mountain next to Tiang Tanjung village) is the important mythological figure who introduced the tradition of baras banyu/ baras kuning (rice mixed with coconut oil and turmeric and used as a magic potion to protect and save people from wicked spirits or persons). Bunga Putih is the prominent pamaliatn who dwells at the top of Bawakng Mountain.

From Bawakng Mountain as a starting point, we can see the possibility of syncretism between traditional Salako Dayak culture and Hinduism. Salako Dayaks have many deities who stay in the land of deities in Bawakng Mountain; in fact every place has its own deity. Dunselman (2016:139-140) recorded the names of Dayak deities in the form of a litany. These deities are basically similar with Hindu deities, which lends weight to the hypothesis that syncretic phenomena have occurred in a mythologized Bawakng Shrine.

\section{METHODOLOGY}

This research is a qualitative and ethnographic based on data and information collected in Bengkayang and Landak Districts. It was obtained through observation, walk-through, and in depth interviews. The data of Salako Dayak cosmogony has been gotten from oral traditions via field work and literature study. These data were then classified and categorized to support the writing of this paper. Most of the data are in the form of oral traditions, therefore, the data collection was conducted by recording the informants then by transcribed the recording into text. After that, the data was analyzed and interpreted qualitatively from a social scientific perspective, utilizing local knowledge from informants in order to know the locals' point of view. In other words, the expression of meaning of the oral traditions (cosmogony) carried out based on emic (the investigated community) and etic (the researcher's point of view) principals.

The research sites are located in two districts, Landak and Bengkayang, simply because the Dayak community in these two districts have a similar belief in Bawakng Mountain as a mythologized mountain of supreme shrine for dieties. The second reason is because this mythologized mountain is surrounded by two subethnic groups, named Bakati Dayak and Banana' Dayak linguistically. These two Dayak sub-ethnic groups claim that Bawakng mountain is their supreme shrine based on their mythology.

The informants were selected based on three categories, namely key informant, expert informant and incidental informant. The key 
informant was selected based on the assumption that they abundantly mastered local wisdom and knowledge. Expert informants are those that have a great understanding of the research issues, therefore they can clarify various data collected. Incidental informants are anybody who can give additional information about research's questions.

The primary data was collected by using the methods of observation, in-depth interview and walkthrough, meanwhile the secondary data derives from the articles, books, documents or file resources about the research's questions.

\section{RESULT AND DISCUSSION}

\section{Salako Dayaks at a glance}

Salako is the ethnonym which is used by the Dayak ethnic group community who live on the border of Sarawak, Malaysia and West Kalimantan, Indonesia on the island of Borneo. This term is considered a derivative of 'sa-ako' from 'salak' and 'lako', the word 'salak' meaning 'barking' and the word 'lako' meaning 'big dog'. According to legend, in ancient times, many big dogs roamed the jungle surrounding the village, and at night the dogs barked and intimidated the villagers (Simon Takdir, 2015:115). The second legend's version states that Salako derives from 'salah' means 'wrong' and 'kao, means 'you'. This term appeared in the heated debate among the group of Salako people who tried to migrate from their homeland in Pakana village in the upper Mampawah river basin to Lundu, Sarawak, to find new land for farming. In the middle of their journey, a big river blocked their way and they started to blame each other by saying 'salah kao', meaning 'you are wrong'.

Salako as an ethnonym designates the Badamea-speaking people of two communities who dwell in Lundu Sarawak, Malaysia and Sambas West Kalimantan, Indonesia, in which they often name themselves based on their local regions (binua), such as the Sawak, Gajekng, Garantukng adat territories. The ethnonyms used for selfreference are endonyms, whereas Salako itself is an exonym, meaning an ethnonym which the referent does not use themselves (Rousseau, 1990: 11). Recently, Salako used as a root of an ethnic name also refers to some Malayic-speaking communities in West Kalimantan, Indonesia who dwell in four districts in West Kalimantan of Sambas, Bengkayang, Landak and Pontianak (Simon Takdir et al, 2015).

Salako people are carefree, pleasant natured and kind, though sometimes considered careless and irresponsible. Physically, they are well proportioned, their feet and hands are small, and they are well fed. Lieut. Marryat in Roth (1968: 48) described the Salako people in Lundu generally as follows,

\begin{abstract}
"they are middle-sized, averaging 5 feet 5 inches, but very strong built, and well conditioned, and with limbs beautifully proportioned. In features they differ very much from the piratical inhabitants of these rivers. The head is finely formed, the hair, slightly shaven in front, is all thrown to the back of the head; their cheek bones are high, eyes small, black, and piercing, nose not exactly flat - indeed, in some cases I have seen it rather aquiline; the mouth is larger and lips rather thick, and there is a total absence of hair on the face and eyebrows. Their complexion is somewhat darker than of the generality of Malays. The countenance intelligent, the eye quick and wandering, the forehead of a medium height."
\end{abstract}

A long time ago, Salako people from West Kalimantan migrated to Sarawak (Lundu), arriving as farmers, hunters and gatherers. Since, in the early $20^{\text {th }}$ century, there was a large population of Salako people, and goods regularly flowed from West Kalimantan to Sarawak, Salakos engaged in an activity called semokil, from Dutch 'smokkelen' meaning 'smuggle'. At that time, there were no check points to filter the flow of people and goods. In spite this history, due to their proximity to the borderland area and being of the same lineage on both sides of the border, they can come and go at the borderland without any difficulties. In spite of the smuggling to Lundu through rivers and jungles in and around the borderland, the economic situation in the borderland never improved. The presence and intertwined interaction of Salako communities in West Kalimantan and in Sarawak has played an important role in the history and existence of the Salako community.

The Salako people who have lived in the borderlands of Sarawak and West Kalimantan since ancient times tried to segregate themselves into two castes (social hierarchy) named Salako Gajekng and Salako Sangkuku'but largely failed. According to one prominent Salako figure, 'Nek Dewa', "Gajekng Salako is the most famous elite community with their famous prominent figure named Nek Dibo'". Nek Dewa stated that 'Nek Dibo' was remembered as a warlord who acted as a shelter of the Salako community, simply because he was successful in defending their land and community against attacks of powerful Saribas and Skarang Iban groups. 


\section{Bawakng Mountain as a Supreme Shrine of Deities}

There is a possibility of syncretism in the system of beliefs and cultural values of Salako, who in the ancient times were influenced and infiltered with Indian Brahman (Indian culture brought by Brahmans) who participated in the cultural values of the Salako belief system.

The three main deities of the Salakos such as Nek Nange (Pangira, Patampa and Pajaji), Nek Bikang (Pangedokng), and Nek Lamikng (Pangingu, Pangaradu'atn, Panyaga) indicate the influence of Hindu religious beliefs and the mosaic elements of Vishnu, Brama and Shiwa (The Preserver, The Creator, and The Destroyer) (see also Dunselman 2016:54). Beside the three main deities, Salako people also believe in several subordinate deities who can be found/ traced from several oral traditions and prayers (nyangahatn/ babamang). The subordinate deities dwell in mountain peaks, forests, rivers, villages, land, stones and houses. For instance, in Bawakng Mountain, several Salako Dayak deities are recognized such as Nek Salopo (or Lopo) Panungkakng Bawakng, believed staying in Bawakng Mountain, Ne' Ape' Mantohari (Bawakng's King), Sam Maniamas as the head of the settlement of deities in Bawakng, Dara Amutn (Maniamas' sibling), Marabatn Ampor (the deity's executor), Sa'ali Sabakal living in Sabakal Mountain in Tiang Tanjung village next to Bawakng Mountain, etc. The Salako Dayak believe that nearly all the mountains are the deities' settlement. The spirits of the forefathers called 'awa pawa' by Salako community also believed staying in the houses or settlement area, lands, stones or big trees.

In spite of the fact that many mountains have become shrines of the deities, in the Salako area, only one mountain has become the supreme shrine of the supreme deities, namely Bawakng Mountain. This mountain is believed to be something like a residential zone for the supreme deities. For this reason worshipers direct their prayers there, to the supreme highest spirit. Myths say Nek Lopo Panungkakng Bawakng has been mythologized as a deity who has the responsibility to maintain and guard Bawakng Mountain. According to the legend, one of the supreme deities dwelling in Bawakng abruptly got angry, and without a logical reason he kicked Bawakng Mountain, therefore the mountain rumbled and looked lopsided if seen from a long distance. Nek Lopo was charged, due to his magical power, to stay the mountain from falling down. In order to cool the temper of that supreme deity, a meeting of deities decided to delegate the mission to one of the deities' executioners, named Marabatn Ampor. His main task was to find out what exactly might cause one Supreme Deity to get angry. After the meeting, Marabatn Ampor with his complete uniform consisting of red clothes, a traditional sword called tangkitn and red fabric with rinyuakng leaves wrapped around his head tried to meditate in order to know the cause of the Supreme Deity losing his temper. Finally, the problem was found; it was simply because the Deity's scenery/ view of his woman (female deity) in Panatn Mountain was hindered by another mountain (the settlement of a different male deity) which was adjacent to the two mountains. The deity in Bawakng was jealous because his rival deity who dwelled at the top of the mountain between Bawakng and Panatn tried to tease his woman deity in Panatn Mountain. Therefore, Marabatn Ampor cut off the top of the mountain by his sword and threw it away, which is how that mountain became flat and therefore named Lamat Sepancong.

Nek Salopo was also considered to be the deity who pioneered the customs and traditions of the people in and surrounding the Bawakng area. That is why the direction of devotion is always towards Bawakng Mountain. The memory of Nek Lopo and several deities are renewed by singing devotional songs and praying (Nyangahatn). The devotional songs of Bawakng consist of seven kinds of music, such as: (1) Bawakng Lajakng; (2) Bawakng Samoko; (3) Bawakng Nyang Kodo; (4) Bawakng Joragan; (5) Bawakng Kadedeng; (6) Bawakng Pulo atau Bawakng Panca; and (7) Bawakng Baramutn. According to legend, that music and songs of Bawakng were derived from Nek Saruna Na' Ujatn Jantu'. Nek Saruna na' Ujatn Jantu'inherited these songs and musics from Nek Nyala' nang Nukukng Pajaji. Nek Nyala' is the son of Nek Ape' Mantohari, the Bawakng's Shaman (pamaliatn), (Maniamas Miden Sood 1997, 87-96).

It is believed that the mythologized supreme shrine of Bawakng mountain has three main functions, namely (a) curing the spirit of identity as Salako Dayak (gnoti sauton) and possession; (b) removing diseases and barrenness (in the case of baliatn); and, (c) maintaining peace. The function of curing the spirit of heroism and possession is conducted by $\mathrm{Ne}$ ' Ape' Mantohari (Pamaliatn Bawakng) or Bawakng Shaman (in Landak, in the Ba'ahe-speaking people's version); the function of removing diseases and barrenness became the main task of Nammba Kabayan (the deity who is able to make the woman become pregnant after getting married) and $\mathrm{Ne}$ ' Ape' Mantohari, and the function of maintaining peace and justice is carried out by Sam Maniamas (the head of villages in Bawakng) (Bakati Riok version, see Bambang Bider 1998). 
In reality, Bawakng as a supreme shrine for deities is always mentioned by the Shaman (panyanghatn or pamatek) in his devotions seeking blessings from the Supreme Deity. The wide ranging landscape of the Bawakng Mountain from east to westward has attained the limelight of the shaman and native Salako people until today as the pre-eminent devotional place/ shrine. Contentious issues are that, among groups of Dayak, some declare themselves as most truly originating from Bawakng due to their proximity to the Bawakng area and inheriting its cultural values (belief, customs and tradition) derived from myth and oral tradition. They do not realize that these kind of beliefs, custom and traditions have been derived from a very comprehensive syncretized Hindu tradition.

When Dayaks performed their cult to deities from Bawakng it gives them ritual power and determines their identity as spiritual Dayak people. The various Dayak ethnic groups surrounding Bawakng Mountain display different perspectives of Bawakng: Kanayatn devotees see Bawakng as a palace of Nyabata; Salakos consider Bawakng as paradise where Jubata stays as the spirit medium who exorcises evil spirits; and Bidayuhs see it as the homeland of all creatures before moving to Niut Mountain and then migrating all over the world. The similarity is that at certain dimensions the transcendent creatures can be accessed by the Shaman or ordinary Dayaks as long as they have magical power. They can communicate and stay with deities and sometimes can order the deities to fulfill their needs after they meet certain requirements determined by the world of deities.

Through the use of common prayers in rituals such as nyangahatn/ matek, baliatn, babuis and balenggang, Badamea and Bakati' speaking people emphasize their devotion to reinterpret beliefs and ideas from people surrounding the mountain in a common symbolic language. During the Naik Dango feast (harvest feast), Nyangahatn/Matek/bapamang has matched and amalgamated some of the religious elements from the culture of Hindu supplemented by past local rituals from the tribal Salako/ Kanayatn Dayaks such as offerings of tumpi', poe', bontokng, manok, babotn, rokok and tuak. The amulets and offerings on this occasion are used to stimulate common identity concerns among the Dayaks. In the moment of prayer, audiences are often reminded by the Panyahangatn that their Jubata and awapama (the spirit of ancestors/forefathers) want something, and through his worship to Jubata and awa pama, they empower one another. What $\mathrm{Ne}$ ' Ape' Mantohari applied in his shamanism practices actually has the content/ message of directing orientation to empower their identity. We have the same deity, we have awa pama and Jubata, we are Salako, we speak Badamea, we are Dayaks, these are our customs and traditions, be united. Actually, those are messages of the spirit of heroism and possession inserted into the Salako Dayak suprastructure which are manifested in shamanism, customs and traditions of their traditional livelihood.

It seems that the community members have acquired this mixed faith from Hinduism, Chinese religion and Christian influences, leading to Dayaks who assert their individual and collective identity through those influences. The practice of adat bauma (customs and tradition related to shifting cultivation) for instance, has been influenced by Catholic worship; the offerings and technology are from local traditions but the prayers are in Catholic form; the manner of serving food for one's forefather's spirit (awa pama) and assisting the spirit of awa pama to the river to achieve paradise (subayatn) is also allegedly from China. The most illustrious common denominators of Salako Dayak identity are their vernacular, their history and supra-structure (nyangahatn, panyugu, padagi, pantak, pantulak, mangkok merah) in which they have been projected as the symbols of the Salako cultural heritages derived from syncretism process.

\section{Seeker of New Identity}

The intermingling of Hindu, Buddhist and Christian culture, and the multiple migrations of Austronesian peoples from different ethnic groups and religions have created the Salako Dayak complex structure of today. It creates manifold layers of Salako Dayak culture.

Recent intellectual discourse of 'genuine' Dayak identity conducted by some Dayak intellectuals, is triggering increasing consciousness of Dayaks' native/indigenous roots. These create a situation where in discourse and dialectic discussion have stated to scrutinize of the Salako Dayak identity in the contemporer era due to the development of science and technology, the process of assimilation and integration of Dayak in Borneo cultural space.

For the indigenous roots, the enthusiasm for the uniqueness of Salako Dayak identity needs to be carefully calibrated with their integration in mythologized Bawakng mountain's cultural features; otherwise, it might become detrimental to their self-identity as Salako Dayaks based Bawakng tradition. The integration of outside cultural elements in the local cultural/community space must occur in harmony with their sense of uniqueness within the history of their predecessors and settlement around Bawakng, as it would then 
be able to rearrange their struggle as the seeker of identity. These could be further reshaped by their settlements surrounding Bawakng Mountain, the multi-religious nature of Dayak community, and the diverse nature of their ancestors' spirits under the new influences of missionary religions.

Syncretism among Dayaks can be read in consonance with the fluidity of their identity formation in livelihood based shifting cultivation, a socio-cultural space of mountainous area, multiple religious affiliations, and a sense of dislocation as interior peoples. Experiences of marginalization, slavery, and colonialism in the past deeply affected the habits, ways of thinking, customs, and religious beliefs of the Salako Dayaks who underwent the process of catastrophic when those historical traumatic experiences can not be settled. Therefore, the survival, revitalization, and eventual celebration of Dayak heritage based on native roots in Borneo become a vehicle for them to search for a new identity in multi-lingual and multicultural Borneo. For Salako Dayaks, the process of seeking identity must be based on local values and traditions from their predecessors and Bawakng's myth. Hopefully, The clear identity would save the Salako Dayak from the dangers of exclusionary identity of a dominant culture, which carries social, cultural, and political risks in alienating them from other communities in their environment. The appreciation of the syncretic heritage of the Salako Dayak may encourage them to be partners in the mosaic of communities in Borneo, and this syncretic process will construe their identity as a hybrid identity through the process of syncretism.

\section{CLOSING}

Salako as an ethnic community in West Kalimantan has experienced influence in many aspects of social life from the intermingling of communities and the process of syncretic phenomena. This Dayak ethnic group spread throughout the border of West Kalimantan and Lundu Sarawak. The influence of outside cultures and belief systems from many sources has triggered the awareness of this people to have an identity. The identity phenomena are able to be traced in many parts of social science. The finding states that syncretism has occurred in the system of beliefs and cultural values of Salako, who in ancient times were frequently influenced and infiltraded by Hindu culture.

The three main deities of Salako, Nek Nange (Pangira, Patampa and Pajaji), Nek Bikang (Pangedokng), and Nek Lamikng (Pangingu, Pangaradu'atn, Panyaga) indicate the influence of Hindu religious beliefs.

The world of deities in Bawakng Mountain are very accessible to certain Dayak groups if the proper requirements are fulfilled. For instance, someone must be a shaman who can communicate with the deities or spirits in certain sacred ceremonies, for example the traditional Dayak healing ceremony called baliatn. Pamaliatns who cure disease pursue the spirit of the sick person that has roamed to the land of the spirits.

For Dayaks, there are two categories of sickness. The first occurs when a person's spirit leaves his body and goes to the world of spirits and deities, while the second is when an evil spirit enters the the person's body and mind. Based on these two categories, Salako Dayaks have developed a suitable method to cure disease, named baliatn.

In order to practice baliatn, a pamaliatn must have certain qualification in order to link with the world of spirits and/ or the world of deities in and around Bawakng Mountain. This healing baliatn is a typical Dayak healing method and derived from and taught by Bujakng Nyangko, one of the supreme deities who dwells on Samabue Mountain, and then inhereted by Bunga Putih who stay at the top of Bawakng Mountain.

From oral traditions collected during field work, based on the study of their cosmogony that syncretic phenomena appear in the relationship between human beings in the real world, spirits that inhabit the land of spirits, and deities that inhabit the world of deities. These three worlds are able to connect and have a special link with one another. We can compare this case with the Hinduism of the Indonesian version of Ramayana, where Resi Gotama (a hermit) marries Retna Windradi (a very beautiful woman from Suralayal Kayangan) meaning paradise, and they have three children Retna Anjani, Subali and Sugriwa. Retna Anjani, the oldest, is as beautiful as her mother, she got cupu manik astagina, a kind of women's ornament or emblem from her mother. Resi Gotama became angry with his wife when he found out that his wife got the cupu manik astagina from her old lover, Betara Endra (the deity of the sun). Simply because he had divine power, he said to his wife, "Windradi, you are so kind, I questioned you three times, but you were silent only, so it is better for you to be silenced forever like a statue. She then became stone. Shortly, сири manik astagina then was thrown by Resi Gotama and became a lake. Subali and Sugriwa jumped into the water, under the surface. When they arose they were monkeys, but Retna Anjani who only washed her face then had a hairy face and hands. To regain her beauty like a human being, she meditated and prayed to Maha Guru (the highest deity in Suralaya/Paradise). After meditating and praying for years, Maha Guru and some Suralaya/ Kayangan inhabitants visited her. At that time Retna Anjani was fully naked, just using her hair to 
cover her body. Seeing her beautiful body, Batara Guru became erect and ejaculated, his sperm landing on a kamal leaf. The leaf then dropped onto Retna Anjani. She ate the leaf and became pregnant. Shortly, she then gave birth to Anoman (See: Sunardi, 1979).

From the story of Ramayana and from the Bawakng tradition we see some similarities, that human beings, spirits and deities who live in different worlds are able to have a special link, even have social interactions like married relations, etc. We also can identify similarities in the existence of deities and their duties and responsibilities. In these two cultures, there must be syncretic phenomena which was inherited from one another.

\section{CONCLUSION}

Salako is the ethnonym to denominate the ethnic group who dwells in the borderlands of two nationstates, Sarawak, Malaysia and West Kalimantan, Indonesia. The historical background of their ancestors and the belief system of this community are closely related with the existence of local cultural values based in Bawakng's traditions and the process of inter-mingling with Hindu beliefs during the Indianization process in Southeast Asia.

Salako people as indigenous peoples in Borneo were influenced by many religious and cultural values. These influences have the possibility of creating a syncretic heritage. "Syncretism is a union or attempted fusion of different religions, cultures, or philosophies, the attempted reconciliation of different opposing principles, practices, or parties, as in philosophy or religion, or the combination of different forms of belief or practice." (Source: Wikipedia) The outside influences which occurred in ancient times, especially during the process of Indianization in Southeast Asia, mutated many aspects of socio cultural life in this region. In West Kalimantan, the people base their culture on the myths based in Bawakng Mountain. The cult of Bawakng deities for the Salako Dayak community can be understood as a uniquely creolized cultural production since the presence and existence of the deities were mostly spurred by India- Hindu influence.

The names of the Salako Deities, such as Nek Lamikng, Nek Nange, and Nek Bikang, the three highest supreme deities, have a mythical connection with Brahma, Vishnu and Siwa in Hinduism. The Bawakng traditions can be seen as the amalgamation and intermingling of this religious belief system. The community believes that Bawakng Mountain is the shrine of the supreme deities as well. The interaction and cultural behavior of the deities in this mountain of their residence indicates that syncretism has occurred in Salako Dayak culture. Sometimes the deities also act like human beings, while human beings are also able to adjust their propane nature like deity. The Bawakng Mountain also affects how the Salako community construes itself based on Bawakng-cosmology and belief system mingled with Hindu's culture.

It is an nice surprise the Dayak intellectual to learn and analyze the forgotten Bawakng Mountain as the source of local cultural values and belief. It is also undeniable that the existence of the deities in Bawakng and their presence which has influenced the Dayak religious belief system and cultural values can be understood as syncretism with Indian traditions.

The Hindu cultural heritage can be understood by analyzing the historical background of the Indianization process in ancient times (see Bastin and Benda 1977). In conclusion, the syncretic heritage of cultural values from this area can be seen from the religious beliefs, livelihood, customs and traditions.

\section{RECOMMENDATION}

To know more exactly about the process of syncretism between Hindu culture and the Salakobased Bawakng cultural heritage, it is necessary for interested social scientists to conduct more comprehensive field and literature studies. The findings should clarify the vagueness in several aspects of the syncretism of this area such as the possibility of dispora, the migration of proto-deutro Malay, and other ethnic groups' influences.

\section{BIBLIOGRAPHY}

Bambang Bider. 1998. Kami Yang Tergugah: Tonndo' Liokng Tana' Tarutn Orokng

Emmbakng. Pontianak: Institute Dayakologi.

Bastin, John and Benda, J. Harry. 1977. Sejarah Asia Tenggara Modern. Kuala Lumpur:

Penerbit Dewan Bahasa dan Pustaka Malaysia.

Dunselman, Donatus. 2015. Adat dan bahasa Dayak Kendayan Kalimantan Barat.

Yogyakarta: Penerbit Pohon Cahaya. 
https://en.wikipedia.org/wiki/Syncretism.

Download on 17 October 2016.

M.C. Shadee. 1903-1914. Adat Istiadat Orang Dayak Landak dan Tayan. Translated by

Pastor Yeri OFMCap 2016. Yogyakarta: Penerbit Pohon Cahaya.

Oomen, T.K. 2009. Kewarganegaraan, Kebangsaan, danEtnisitas: Mendamaikan

Persaingan Identitas. Bantul: Kreasi Wacana.

Roth, Hendry Ling. 1968. The Native of Sarawak and British North Borneo. Singapore-Kuala

Lumpur: Penerbit University of Malaya

Press.

Simon Takdir. 2015. Mengenal Dayak Salako.

Dalam Jurnal Budaya, Agama dan Pembelajaran: Omnes et Omnia. Vol. 5

Nomor 2, 2015. Penerbit: Sekolah Tinggi

Pontianak.

Pastoral Santo Agustinus Keuskupan Agung

Simon Takdir, et.al. 2015. Identifikasi Sub-Sub Suku Dayak di Kabupaten Landak dan

Bengkayang Provinsi Kalimantan Barat. Kantor Penelitian dan Pengembangan,

Pemerintah Provinsi Kalimantan Barat.

Temenggung Maniamas Miden Sood. 1997. Musik

Dayak Kanayatn dan Penciptanya dalam

Mencermati Dayak Kanayatn. (Editor): Nico Andasputra, Vincentius Julipin. (Kata

Pengantar): Stepanus Djuweng. Pontianak:

Penerbit Institute of Dayakology Research and Development. 